\title{
The Quality of Life and Human Development Index of Community Living along Pahang and Muar Rivers: A Case of Communities in Pekan, Bahau and Muar
}

\author{
Sulaiman Md. Yassin ${ }^{1}$, Hayrol Azril Mohamed Shaffril ${ }^{1}$, Md. Salleh Hassan ${ }^{1}$, Mohd Shahwahid Othman ${ }^{2}$, \\ Bahaman Abu Samah ${ }^{1}$, Asnarulkhadi Abu Samah ${ }^{3} \&$ Siti Aisyah Ramli ${ }^{1}$ \\ ${ }^{1}$ Institute for Social Science Studies, Universiti Putra Malaysia \\ ${ }^{2}$ Research and Innovation, Faculty of Economics and Management, Universiti Putra Malaysia \\ ${ }^{3}$ Department of Social and Development Science, Faculty of Human Ecology, Universiti Putra Malaysia \\ Correspondence: Sulaiman Md. Yassin, Institute for Social Science Studies, Universiti Putra Malaysia. Tel: \\ 603-89-471-863. E-mail: sulaimanyassin@gmail.com; majudesa.desa@gmail.com
}

Received: March 1, 2012 Accepted: May 10, 2012 Online Published: May 24, 2012

doi:10.5539/jsd.v5n6p90 URL: http://dx.doi.org/10.5539/jsd.v5n6p90

The research is financed by Research University Grant Scheme (Scheme 1) sponsored by Universiti Putra Malaysia

\begin{abstract}
Rivers have something to do with the improvement of the quality of life of the rural community. A lot of benefits can be offered to the river community. This study intends to reveal the level of quality of life of the rural community living along two major rivers in Malaysia, the Pahang and Muar Rivers. Apart from this, this study intends to investigate the level of Human Development Index of the Pahang and Muar River community by using an established human development index known as the Well-o-Meter. This is a quantitative study, where a total of 900 respondents had been selected. A developed questionnaire was used and survey was employed. Based on the results gained, it can be identified that the respondents studied recorded a high level of mean score in the aspects of social involvement and relationship, home condition, safety at the areas and education. The human development index employed have detected that the respondents studied do have a low level of HDI. The findings of the study were further discussed.
\end{abstract}

Keywords: quality of life, human development index, rural community, river development

\section{Introduction}

Doubtlessly a river is precious to us; a source of freshwater from the mountains to the sea. Rivers begin as small trickles of water up in the mountains. This is its source, and it finally forms a small stream which then flows down the mountain and on to the plains. The water erodes the land, carving a bigger channel and forms the main river. Based on statistics, there are 189 river basin systems with about 1800 rivers in Malaysia which cover the total length of $38,000 \mathrm{~km}$. Among the famous rivers in Malaysia are the Pahang River, Kelantan River, Perak River, Kinabatangan River, Muar River and Rajang River. The main roles of rivers is not just supplying the clean water for the community, indeed they have a significant role in uplifting the socio-economic status of the rural community especially those who live along the rivers.

\subsection{Pahang River and Muar River}

Pahang and Muar rivers are two large and important rivers in Malaysia. These two rivers flow through three states in Peninsular Malaysia namely Pahang, Negeri Sembilan and Johor. They also flow through big cities such as Pekan, Temerloh, Kuantan, Bahau, Jempol, Segamat and Muar. Remarkably, the distance between these two rivers is only 300 meters in a place called Penarikan in Negeri Sembilan. At Jalan Penarikan, the boats need to be pulled overland. The distance is manageable and because of the pulling of boats overland, the route is named Penarikan, which is the Malay word for 'pulling'. In the old days, these two rivers were the important waterways for the economic activities of the local populace. These two rivers provided useable route for traders to continue their journey eastwards until they reach Kuala Pahang in Pekan, or Kuala Lipis to continue into Terengganu, 
Kelantan or Perak. Historically, these two rivers are not just a symbol of economic strength of the local people, they were also related to the legendary Malay warrior called Hang Tuah who brought the beautiful princess named "Tun Teja" to Malacca. Furthermore, a lot of famous historical places such Bukit Kepong Police Station, Bombed bridge called "Jambatan Patah", "Kota Buruk" and Lubuk Pahang Tomb can be found along these two rivers (Yassin et al., 2010).

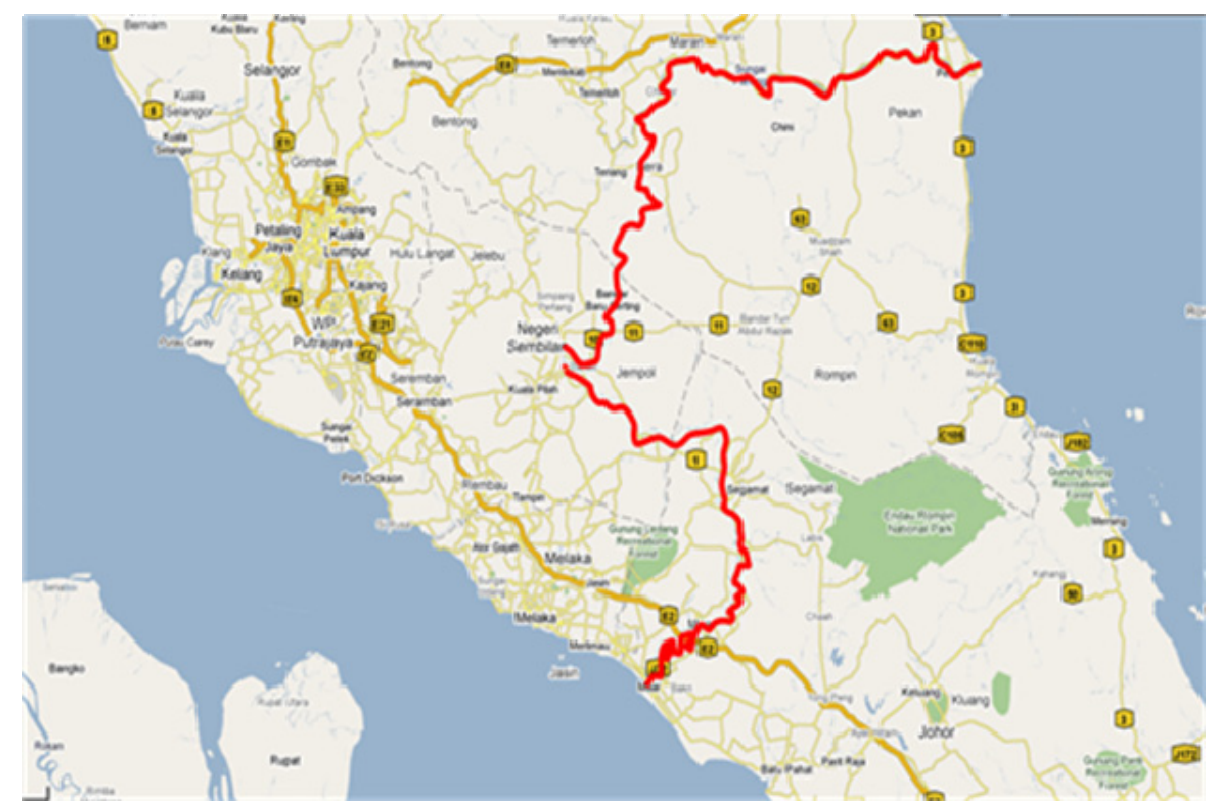

Figure 1. Flows of Pahang River and Muar River

\subsection{Potential Socio-economic Benefits that can be Gained from Pahang and Muar Rivers Development}

\subsubsection{Social Development}

River development has a huge influence on the community's social and economic activities. The community in Pahang, Negeri Sembilan and Johor, the three states through which Pahang and Muar Rivers flow are thus provided the opportunity to uplift and diversify their social development. Doubtlessly, development done on the river can strengthen community and family relationships through social and recreational activities such as picnics, fishing, kayaking/canoeing and other activities. Interestingly, the river development has the cohesive force to unite the community and to add value to the community through a cross border project (for example, inland waterway). Inevitably, this can be one of the mediums in achieving the mission of "One Malaysia", an idea for unity of various races created by the current Prime Minister of Malaysia. The social development is something which is difficult to estimate; nevertheless is it essential due to the greater reward it offers for the community to which it applies (Grumbine \& Xu, 2011; McCartan \& Brady, 2007).

\subsubsection{Increased Income of the Community}

Agriculture is often considered as the main income generator of the rural community (Hayrol Azril et al., 2010). Nevertheless, a river can be one of its catalysts. Promising industries such as tourism, recreational activities, boat making industry, fish rearing, boat renting industry, and agriculture industry can be conducted along the rivers (Ahmad Faiz et al., 2010). All of these will flourish the rural areas, strengthening the economic activities and promote social development and cohesion. Without doubt all of these activities can be conducted along Pahang and Muar Rivers. At Muar River for example, there is the famous police station of Bukit Kepong, the British bombed bridge during World War 2 at Buloh Kasap, Sultan Ibrahim Mosques and the Tun Teja tomb and all of these should be preserved and developed as tourism sites which can provide a lot of economic opportunities for the locals. A number of previous studies have proven that through recreational activities along the river, money making activities can be conducted (Azlina et al., 2010; Ericson \& Ronning, 2008; Theerapappisit, 2003; Kristensen, 2001). Activities such as fish and river lobster fishing, boat renting, tourism, restaurants and hotels for example have a huge potential to be developed along the river. 


\subsubsection{Rural Development through Economic Development Opportunity}

River development can be a good source for bulk commodities transportation and agricultural activities. In the rural area, river development is essential to ensure the persistence of the economic health (Yassin, et al., 2010; Jianwu et al., 2010). River development will offer economic opportunities for some remote and undeveloped rural areas (City of Hood River, 2011). It will create business opportunities for rural enterprise development that are currently absent in the area. This is essential especially in an area where declining agricultural base needs to be supported by diversification of economic activities. Small Medium Enterprises (SMEs) activities and industries either big or small can be conducted along the rivers by the interested local community. Furthermore, river related economic activities such as boat making industry, fish cage culture, boat renting industry, agriculture industry and tourism industry are among the activities that shall flourish (Ahmad Faiz et al., 2010; Raja Zainudin et al., 2011). Besides generating economic activities, it can help to promote social development and cohesion. This is of particular importance in an area where communities have been separated by the State borders. River development would not alone be visually pleasing, but can be the catalyst in creating strong communities and enable these communities to reach their full potential.

\subsubsection{As the Source of Protein}

Rivers have continuously provided us with tons of sources of protein. Pahang and Muar Rivers for examples that are famous with its fresh river lobster and some species of fishes. Even though the number is lessen due to the rapid development of commodity plantation the river communities in Pahang and Muar Rivers seem to still depend on the two rivers (Yassin et al., 2010).

\subsubsection{Alternative Transportation}

River transport is a good form of alternative transportation which enables the communities to go to other cities, town or other areas (Misra, 2007; Sudar, 2005). One of the potentials that Pahang and Muar rivers have is the construction of the inland waterway. Inland waterway creates alternatives and additional choice for people to move between cities and major sites of manufacturing, industry and commerce (Misra, 2007). Having this potential is good news for the community; they offer alternative transportation for community especially those in urban areas for going back to their villages during the festive seasons such as "Hari Raya", Chinese New Year" and "Deepavali" which are crucial holidays for Malaysians. Previously the Muar River route from Bukit Kepong to Muar was the main route to transport the palm oil during 1930 till 1950. Besides, there was also a ferry service during 1950s that plied from Bukit Kepong to Singapore (Yassin et al., 2010).

\subsubsection{Enhancing Quality of Life}

River development has something to do with uplifting the rural community quality of life (Yassin et al., 2010). Doubtlessly, rivers are able to provide sustainable economic benefits to local businesses and communities' at large (Hitzhusen et al., 1999; Hamilton, et al., 1999). This is about enhancing the objective-well-being of the communities. Rivers can play a role in supporting sustainable transport in urban and rural areas (Misra, 2007). In addition, their diversity, beauty, history and natural environment contribute to the health and the subjective well-being of individuals and society. The surroundings with which they communicate daily, greenery, open spaces and the wider environment, a totality of which the rivers are an important component, are part of their own heritage, contributing to their individual and collective quality of life. In conclusion, both the subjective well-being and objective well-being of the communities in the affected area could be enhanced and improved.

\subsection{Malaysian Rural Community Quality of Life}

Quality of life, happiness, wellbeing, and utility are often seen as one and they are frequently used interchangeably. Quality of life can be defined as an individual's perception of their position in life in the context of the culture and value systems in which they live and in relation to their goals, expectations, standards, and concerns (WHOQOL Group, 1993). Malaysia has experienced a well planned development which was largely provided by the rapid economic growth and transformation. One of the beneficiaries of these developments is the rural community. Results of these developments have reflected a better quality of life among the rural community in Malaysia. Among the major indicators of the better quality of life benefited by the rural community is in terms of their income. In 1999, it can be identified that the monthly income per month per rural household was RM 1,718. Nevertheless, the income level has increased to RM 2,545 in 2009 (Ministry of Rural and Regional Development, 2011).

Efforts to develop the rural areas and the rural community have never been stopped. Government has placed its full effort to ensure that the rural community will benefit from the development has brought to be as equitable as their counterpart in the urban areas. This can be proven as in The Tenth Malaysia Plan (10MP), in which a total 
of RM145 billion will be allocated for the physical, economic and social development of the rural areas. In terms of education aspect, it is good to know that up to this date almost a half million of the rural students were given chances to continue their studies at the public universities. To ensure that the rural community will have better access to the cities, in the period of four years from 2006 to 2009, a total of 1,419.26 km of new and repaired roads have been made available in the rural areas. Health services provided to the rural community have been well developed in Malaysia, and to ensure that the rural community will continue to enjoy a better access to the health services provided by the government, a total of 1927 rural clinics were established in the rural areas (Ministry of Rural and Regional Development, 2011).

In 2010, a total of 29,523 houses in rural areas especially in Sabah/Sarawak zone have been provided with electric supply (14,140 houses) and tap water (15,383 houses) (Ministry of Rural and Regional Development, 2011). Furthermore, the Malaysia National Key Result Areas (NKRAs) has been introduced and one of the main beneficiaries of this NKRA are the rural communities. Six (6) NKRAs have been introduced and it includes 1) reducing the crime rates; 2) combating corruption; 3) widening access to affordable and quality education areas; 4) raising the living standard of the poor; 5) improving the infrastructure in rural areas and 6) improving public transport in the medium term. Facts given above are the general data of the QOL of the rural community in Malaysia but not looking specifically into the QOL of the rural community who live along Pahang River and Muar River which this study will be focussed upon.

\subsection{What is Human Development?}

Human development concept is an important concept to be understood. Human development is the process of exposing people to freedom and opportunities and in alleviating their well-being. In human development, real freedom is the most important element and the ordinary people have the right and choices to decide who they want to be, what they want to do, and how they want to live; meaning that they have absolute freedom to do all these. Mahbub ul Haq is an economist, the founder and creator of the concept of human development. He claimed that existing measures of human progress were unsuccessful to account for the true purpose of development which is to improve people's lives. Among the common themes that have usually been regarded as fundamental to human development are social progress, economics, efficiency, equity, participation and freedom, sustainability and human security (UNDP HDI Report, 2010).

There are lot of human development definitions and among the popular ones are:

The basic purpose of development is to enlarge people's choices. In principle, these choices can be infinite and can change over time. People often value achievements that do not show up at all, or not immediately, in income or growth figures: greater access to knowledge, better nutrition and health services, more secure livelihoods, security against crime and physical violence, satisfying leisure hours, political and cultural freedoms and sense of participation in community activities. The objective of development is to create an enabling environment for people to enjoy long, healthy and creative lives-Mahbub ul Haq (1934-1998) Founder of the Human Development Report- quotation from http://hdr.undp.org/en/humandev/

"Human development, as an approach, is concerned with what I take to be the basic development idea: namely, advancing the richness of human life, rather than the richness of the economy in which human beings live, which is only a part of it." Prof. Amartya Sen Harvard University quotation from http://hdr.undp.org/en/humandev/

\subsubsection{The Human Development Index}

The Human Development Index (HDI) is an essential tool for creating a simple money metrics. It is a simple and easy-to-understand index based on the measurement of three basic human needs which are health; income and education. HDI was first established in 1990 and after that numerous efforts have been put to develop a new and improved HDI. A number of governments in the world have employed the HDI to produce official government statistics; its annual publication inaugurates serious political discussion and renewed efforts, nationally and regionally. One of the established HDI was created by American Human Development Project of the Social

Science Research Council which can be accessed online through http://www.measureofamerica.org/well-o-meter/. It is a modified American Human Development Index and it measures three common things of HDI, they being health, income and education. Nevertheless it uses different indicators to suit the U.S. context and to maximize the use of available data (The American Human Development Project Social Science Research Council, 2011). Malaysia has been ranked $57^{\text {th }}$ in terms of HDI (Human Development Report, 2010). Besides the fact provided by such report, it is good to employ the American Index in the Malaysian context especially for those who live in the rural areas. By doing this we can identify the HDI level of rural community in Malaysia if they are to be compared to the other communities living in the developed countries such as the USA. 


\section{Methodology}

This is a quantitative study and data were collected using a developed questionnaire. The main purpose of this study is to investigate the level of QOL and HDI of the communities living along Pahang River and Muar River. A total of 900 respondents were selected in this study where the number was gained from communities in three cities along Pahang River and Muar River namely Pekan (in Pahang), Bahau (in Negeri Sembilan) and Muar (in Johor). Each of the cities was represented by 300 respondents who live near to both rivers. The first part of the study focused on the QOL of the respondents where a total of seven aspects have been included and the aspects were 1) home condition; 2) physical environment; 3) safety at the areas; 4) social involvement and relationship; 5) education; 6) financial and job security and 7) infrastructure facilities. Overall, these seven aspects consist of 51 questions and the distribution of the questions for each of the aspect of the quality of life are described as in Table 1.

Table 1. Aspects of quality of life studied

\begin{tabular}{cc}
\hline Aspects of quality of life & Number of questions \\
\hline Home condition & 11 \\
Physical environment & 7 \\
Safety at the areas & 7 \\
Social involvement and relationship & 9 \\
Education & 5 \\
Financial and job security & 7 \\
Infrastructure facilities & 5
\end{tabular}

The respondents were given an option of five likert-scale answer ranging from 1) very unsatisfied; 2) unsatisfied; 3 ) moderately satisfied; 4) satisfied and 5) very satisfied. To identify the suitable respondents, assistance from the village leaders were gained and a total of 61 villages along Pahang River and Muar River were involved in this study. Trained enumerators facilitated the face to face interview to gain the data needed. To run the suitable analyses, descriptive analyses such as frequency, percentage, mean and standard deviation were performed to describe the general data of the respondents studied.

For gaining the HDI of the respondents, the questions were based on the well-o-meter website which can be accessed at http://www.measureofamerica.org/well-o-meter/. The index consists of 26 questions which focuses on three parts namely 1) Health 2) Income and 3) Education. After the HDI was calculated at the well-o-meter website, the HDI value then was keyed in into SPSS to gain the cumulative value of the HDI.

\section{Result}

Before we discuss the main objective of this study, it is better to get to know the demographic data of the respondents. In terms of job category, slightly more than a quarter of the respondents $(26.0 \%)$ were housewives while slightly more than one fifth of the respondents $(20.2 \%)$ were self-employed while a total of $13.6 \%$ of the respondents were working in agriculture related works. Interestingly, this study has found that only a total of $28.7 \%$ of the respondents earned incomes below the poverty level $(<\mathrm{RM} 720)$. A total of $36.4 \%$ of the respondents have stayed at the village for $\geq 51$ years while a total of $35.8 \%$ have stayed at the village for $26-50$ years. Majority of the respondents can be considered to live not too far away from the nearest city based on the mean score recorded $(\mathrm{M}=10.98 \mathrm{~km})$. More than a quarter of the respondents $(25.6 \%)$ stayed $<250$ meters from Pahang or Muar River while a total of $26.3 \%$ of the respondents stayed between 251 meters-500 meters from Pahang or Muar River. Majority of the respondents studied have between 3-5 household members (Table 2). 
Table 2. Socio-demographic data of the respondents

\begin{tabular}{|c|c|c|c|c|}
\hline Level & Frequency & Percentage & Mean & SD \\
\hline \multicolumn{5}{|l|}{ Job category } \\
\hline Housewife & 234 & 26.0 & & \\
\hline Self-employed & 182 & 20.2 & & \\
\hline Agriculture related & 122 & 13.6 & & \\
\hline Retiree & 116 & 12.9 & & \\
\hline Private sector & 89 & 9.9 & & \\
\hline Government sector & 81 & 9.0 & & \\
\hline Others & 76 & 8.4 & & \\
\hline \multicolumn{5}{|l|}{ Poverty Level (PL) } \\
\hline Below PL $(<$ RM720) & 258 & 28.7 & & \\
\hline Above PL $(>\mathrm{RM} 721)$ & 642 & 71.3 & & \\
\hline Period of staying at the village (years) & & & 40.90 & 21.60 \\
\hline$<25$ & 250 & 27.8 & & \\
\hline $26-50$ & 322 & 35.8 & & \\
\hline$\geq 51$ & 328 & 36.4 & & \\
\hline Distance to the nearest city $(\mathrm{km})$ & & & 10.98 & 10.39 \\
\hline$\leq 5 \mathrm{~km}$ & 326 & 36.2 & & \\
\hline 6-10 km & 259 & 28.8 & & \\
\hline$\geq 11 \mathrm{~km}$ & 315 & 35.0 & & \\
\hline Distance to nearest river & & & 0.86 & 0.65 \\
\hline$<250$ meter & 230 & 25.6 & & \\
\hline 251-500 meter & 237 & 26.3 & & \\
\hline $501-1000$ meter & 233 & 25.9 & & \\
\hline $1 \mathrm{~km}-2 \mathrm{~km}$ & 200 & 22.2 & & \\
\hline \multicolumn{5}{|l|}{ Number of family members } \\
\hline $1-2$ & 200 & 22.2 & & \\
\hline $3-5$ & 400 & 44.4 & & \\
\hline $6-7$ & 187 & 20.8 & & \\
\hline$\geq 8$ & 111 & 12.3 & & \\
\hline
\end{tabular}

To gain the overall level of the QOL of the respondents studied the cumulative value of the seven aspects of QOL was calculated. Then, the value was categorized into three levels namely low (1-2.33); moderate (2.34-3.67) and high (3.68-5.00) respectively. Based on the mean score recorded, slightly more than half of the respondents $(50.6 \%)$ had a moderate level of QOL while a total of $49.2 \%$ of the respondents had a high level of QOL. Only $0.2 \%$ of the respondents were found to have a low level of QOL (Table 3).

Table 3. Overall level of quality of life

\begin{tabular}{ccccc}
\hline QOL & Frequency & Percentage & M & SD \\
\hline Overall level of QOL & & & $\mathbf{3 . 6 4}$ & $\mathbf{. 4 1 3}$ \\
Low (1-2.33) & 2 & .2 & & \\
Moderate (2.33-3.66) & 455 & 50.6 & & \\
High (3.67-5.00) & 443 & 49.2 & & \\
\hline
\end{tabular}




\subsection{Aspects of Quality of Life Studied}

As has been clarified in the methodology part, this study consists of seven aspects of QOL. The highest overall mean score was recorded by the aspect of social involvement and relationship $(\mathrm{M}=3.94)$ while the lowest mean score was recorded by the aspect of infrastructure facilities $(M=3.12)$. Based on the results, it can be concluded that four aspects of QOL recorded a high level of overall mean scores and the aspects were 1) social involvement and relationship; 2) home condition; 3) safety at the areas and 4) education. The other three aspects were recorded to score a moderate level of overall mean scores and the aspects were 1) physical environment; 2) financial and job security and 3 ) infrastructure facilities (Table 4).

Table 4. Aspects of quality of life studied

\begin{tabular}{ccccc}
\hline Quality of life aspects & Pekan & Bahau & Muar & Overall mean score level \\
\hline Social involvement and relationship & $\mathbf{M}=\mathbf{4 . 0 6}$ & $\mathbf{M}=\mathbf{3 . 9 3}$ & $\mathbf{M}=\mathbf{3 . 8 1}$ & $\mathbf{M}=\mathbf{3 . 9 4}$ \\
Low (1-2.33) & 0.7 & 0.3 & 1.0 & \\
Moderate (2.33-3.66) & 24.7 & 35.3 & 41.0 & \\
High (3.67-5.00) & 74.6 & 64.4 & 58.0 & $\mathbf{M}=\mathbf{3 . 9 1}$ \\
Home condition & $\mathbf{M}=\mathbf{3 . 8 1}$ & $\mathbf{M}=\mathbf{4 . 0 2}$ & $\mathbf{M}=\mathbf{3 . 9 0}$ & \\
Low (1-2.33) & 0 & 0.7 & 0.7 & \\
Moderate (2.33-3.66) & 38.3 & 25.0 & 27.7 & \\
High (3.67-5.00) & 61.7 & 74.3 & 71.6 & $\mathbf{M}=\mathbf{3 . 7 9}$ \\
Safety at the areas & $\mathbf{M}=\mathbf{3 . 9 3}$ & $\mathbf{M}=\mathbf{3 . 6 2}$ & $\mathbf{M}=\mathbf{3 . 8 1}$ & \\
Low (1-2.33) & 0.3 & 3.0 & 1.7 & \\
Moderate (2.33-3.66) & 27.3 & 51.7 & 31.7 & $\mathbf{M}=\mathbf{3 . 7 3}$ \\
High (3.67-5.00) & 72.3 & 45.3 & 66.7 & \\
Education & $\mathbf{M}=\mathbf{3 . 7 2}$ & $\mathbf{M}=\mathbf{3 . 7 2}$ & $\mathbf{M}=\mathbf{3 . 7 7}$ & \\
Low (1-2.33) & 0 & 0.3 & 0.7 & $\mathbf{M}=\mathbf{3 . 5 0}$ \\
Moderate (2.33-3.66) & 54.0 & 49.7 & 40.0 & \\
High (3.67-5.00) & 46.0 & 50.0 & 59.3 & \\
Physical environment & $\mathbf{M}=\mathbf{3 . 6 2}$ & $\mathbf{M}=\mathbf{3 . 3 6}$ & $\mathbf{M}=\mathbf{3 . 5 3}$ & \\
Low (1-2.33) & 0 & 0.3 & 1.7 & \\
Moderate (2.33-3.66) & 61.0 & 79.7 & 59.0 & $\mathbf{M}=\mathbf{3 . 4 8}$ \\
High (3.67-5.00) & 39.0 & 20.0 & 39.3 & \\
Financial and job security & $\mathbf{M}=\mathbf{3 . 3 3}$ & $\mathbf{M}=\mathbf{3 . 4 9}$ & $\mathbf{M}=\mathbf{3 . 5 8}$ & \\
Low (1-2.33) & 8.3 & 15.7 & 8.7 & \\
Moderate (2.33-3.66) & 54.7 & 31.7 & 39.3 & $\mathbf{3 . 1 2}$ \\
High (3.67-5.00) & 37.0 & 52.6 & 52.0 & \\
Infrastructure facilities & $\mathbf{M}=\mathbf{3 . 1 0}$ & $\mathbf{M}=\mathbf{2 . 9 9}$ & $\mathbf{M}=\mathbf{3 . 2 8}$ & \\
Low (1-2.33) & 11.3 & 19.3 & 11.7 & \\
Moderate (2.33-3.66) & 70.7 & 63.7 & 58.7 & \\
High (3.67-5.00) & 18.0 & 17.0 & 29.6 & \\
& & & & \\
\hline
\end{tabular}

For the aspect of social involvement and relationship, nearly three quarters of the respondents in Pekan (74.6\%) were found to have a high level of mean score in this aspect. In Bahau, a total of $64.4 \%$ of the respondents were detected to have a high level of mean score in this aspect while in Muar a total of $58.0 \%$ of the respondents were identified to score a high level of mean score in this aspect.

For the aspect-of home condition, respondents in Bahau were found to score the highest mean score $(M=4.02)$. The second highest mean score was recorded by respondents in Muar $(\mathrm{M}=3.90)$ and respondents in Pekan recorded to score the third highest mean score $(\mathrm{M}=3.81)$.

Majority of the respondents studied did feel that their areas were safe and this can be proven based on the high overall mean score recorded $(\mathrm{M}=3.79)$. Looking specifically at each area studied, respondents in Pekan $(\mathrm{M}=$ 3.93) and Muar $(\mathrm{M}=3.81)$ managed to score a high level of mean score while respondents in Bahau $(\mathrm{M}=3.62)$ managed to score a moderate level of mean score. 
Education is an important key for success in everything and it is good to know that majority of the respondents studied were identified to score a high level of mean score in this aspect (M 3.72). A total of $59.3 \%$ of the respondents in Muar recorded a high level of mean score in this aspect. Half of the respondents in Bahau (50.0\%) and nearly half respondents in Pekan (46.0\%) recorded a high level of mean score in this aspect.

In terms of physical environment, majority of the respondents studied have a moderate level of mean score. This can be proven based on the majority of the respondents in Bahau (79.7\%), Pekan (61.0\%) and Muar (59.0) were found to score a moderate mean score in this aspect.

A total of $52.6 \%$ of respondents in Bahau and $52.0 \%$ of the respondents in Muar were found to chart high mean scores towards the aspect of financial and job security while majority respondents in Pekan (54.7\%) were found to have a moderate level of satisfaction towards this aspect. Last but not least, for the aspect of infrastructure facilities, majority of respondents in Pekan $(70.7 \%)$ were found to have a moderate mean score towards this aspect. Interestingly, majority of respondents in the other two cities; Bahau (63.7\%) and Muar (58.7\%) also recorded a moderate mean score towards the aspect of infrastructure facilities.

\subsection{The Human Development Index for Pekan, Bahau and Muar Community}

For the second part of the study, it focuses on the HDI of the respondents. First, it focuses on the health of the respondents. In this part a total of 24 questions were asked to the respondents. More than half of the respondents were male $(55.3 \%)$. A total of $46.1 \%$ of the respondents were between 50 to 70 years old. All of the respondents live in the rural areas with populations of less than 2 million people. A large majority of the respondents (72.8\%) had their grandparents who did not past the age of 85 years while a total of $30.3 \%$ of the respondents had stated that all of their grandparents lived to age 80. Respondents were also questioned whether either one of their parents died of a stroke or heart attack before reaching the age of 50 and results presented in Table 5 shows that a total of $86.2 \%$ of the respondents answered "no" to this question. Interestingly, more than three quarters of the respondents $(76.9 \%)$ have none of their parents, brothers or sisters under the age of 50 who has (or had) cancer, heart condition or has diabetes. Minority of the respondents were over 65 years and still working while $95.2 \%$ of the respondents indicated that they live with spouses or friends. In terms of type of jobs, a total of $93.1 \%$ of the respondents were not working behind a desk. Minority of the respondents $(20.6 \%)$ insisted their work does require heavy physical efforts. It can be identified that more than half of the respondents (56.4\%) only practice less than two times a week strenuous exercise for at least half an hour. This study also revealed that majority of the respondents did not sleep more than 10 hours a night $(81.0 \%)$, were not intense, aggressive and easily angered $(97.3 \%)$, are easy going and relaxed $(98.6 \%)$ and have no speeding ticket last year $(88.1 \%)$. Only one respondent $(0.1 \%)$ was detected to drink equivalent of two drinks of liquor a day. It is a good indicator that a total of $73.1 \%$ of the respondents were not overweight and a large majority of the respondents $(83.9 \%)$ did conduct annual medical checkups. 
Table 5. HDI Part 1(Health)

\begin{tabular}{|c|c|c|c|c|}
\hline Level & Frequency & Percentage & Mean & SD \\
\hline \multicolumn{5}{|l|}{ Gender } \\
\hline Male & 498 & 55.3 & & \\
\hline Female & 402 & 44.7 & & \\
\hline Age (years) & & & 53.5 & 14.6 \\
\hline under 30 & 64 & 7.1 & & \\
\hline between $30-40$ & 104 & 11.6 & & \\
\hline between $40-50$ & 200 & 22.2 & & \\
\hline between $50-70$ & 415 & 46.1 & & \\
\hline over 70 & 117 & 13 & & \\
\hline \multicolumn{5}{|c|}{$\begin{array}{l}\text { Live in Urban Areas with the population more } \\
\text { than } 2 \text { million }\end{array}$} \\
\hline Yes & 0 & 0 & & \\
\hline No & 900 & 100 & & \\
\hline \multicolumn{5}{|c|}{$\begin{array}{l}\text { Has one of your grandparents live to age } 85 \text { or } \\
\text { more }\end{array}$} \\
\hline Yes & 245 & 28.2 & & \\
\hline No & 655 & 72.8 & & \\
\hline \multicolumn{5}{|c|}{$\begin{array}{l}\text { Have all of your grandparents lived to age } 80 \text { or } \\
\text { more }\end{array}$} \\
\hline Yes & 273 & 30.3 & & \\
\hline No & 627 & 69.7 & & \\
\hline \multicolumn{5}{|c|}{$\begin{array}{l}\text { Has either one of your parents died of a stroke of } \\
\text { heart attack before } 50\end{array}$} \\
\hline Yes & 124 & 13.8 & & \\
\hline No & 776 & 86.2 & & \\
\hline \multicolumn{5}{|c|}{$\begin{array}{l}\text { Has any parents, brother or sister under the age } \\
\text { of } 50 \text { has (or had) cancer of a heart condition or } \\
\text { has diabetes }\end{array}$} \\
\hline Yes & 208 & 23.1 & & \\
\hline No & 692 & 76.9 & & \\
\hline \multicolumn{5}{|c|}{ Are you over 65 and still working } \\
\hline Yes & 91 & 10.1 & & \\
\hline No & 809 & 89.9 & & \\
\hline \multicolumn{5}{|c|}{ Do you live with a spouse or friend } \\
\hline Yes & 857 & 95.2 & & \\
\hline No & 43 & 4.8 & & \\
\hline \multicolumn{5}{|c|}{$\begin{array}{l}\text { How many years have you lived alone since age } \\
25 \text { (years) }\end{array}$} \\
\hline 0 & 803 & 89.2 & & \\
\hline $1-5$ & 59 & 6.6 & & \\
\hline $6-10$ & 16 & 1.8 & & \\
\hline$>10$ & 22 & 2.4 & & \\
\hline \multicolumn{5}{|c|}{ Do you work behind a desk } \\
\hline Yes & 62 & 6.9 & & \\
\hline No & 838 & 93.1 & & \\
\hline \multicolumn{5}{|c|}{ Does your work require heavy physical work } \\
\hline Yes & 185 & 20.6 & & \\
\hline No & 715 & 79.4 & & \\
\hline \multicolumn{5}{|c|}{$\begin{array}{l}\text { How long do you exercise strenously (tennis, } \\
\text { running, etc) a week for at least } 1 / 2 \text { hour }\end{array}$} \\
\hline 5 times & 196 & 21.8 & & \\
\hline 2-3 times & 196 & 21.8 & & \\
\hline Less than two times & 508 & 56.4 & & \\
\hline \multicolumn{5}{|c|}{ Do you sleep more than 10 hours each night } \\
\hline Yes & 81 & 9.0 & & \\
\hline No & 819 & 81.0 & & \\
\hline \multicolumn{5}{|c|}{ Are you intense; aggressive or easily angered } \\
\hline Yes & 24 & 2.7 & & \\
\hline No & 876 & 97.3 & & \\
\hline
\end{tabular}


Table 5. HDI Part 1(Health) (Continued)

\begin{tabular}{|c|c|c|c|c|}
\hline Level & Frequency & Percentage & Mean & SD \\
\hline \multicolumn{5}{|c|}{ Are you easy-going and relaxed } \\
\hline Yes & 887 & 98.6 & & \\
\hline No & 13 & 1.4 & & \\
\hline \multicolumn{5}{|l|}{ Are you happy } \\
\hline Yes & 891 & 99.0 & & \\
\hline No & 9 & 1.0 & & \\
\hline \multicolumn{5}{|l|}{ Are you unhappy } \\
\hline Yes & 16 & 1.8 & & \\
\hline No & 884 & 98.2 & & \\
\hline \multicolumn{5}{|c|}{ Have you had a speeding ticket last year } \\
\hline Yes & 107 & 11.9 & & \\
\hline No & 793 & 88.1 & & \\
\hline \multicolumn{5}{|c|}{$\begin{array}{l}\text { Do you drink equivalent of two drinks or liquor a } \\
\text { day }\end{array}$} \\
\hline Yes & 1 & .1 & & \\
\hline No & 899 & 99.9 & & \\
\hline \multicolumn{5}{|l|}{ Are you overweight } \\
\hline I'm not overweight & 658 & 73.1 & & \\
\hline By 10 to 30 pounds & 125 & 13.9 & & \\
\hline By 30 to 50 pounds & 99 & 11.0 & & \\
\hline By 50 pounds or more & 18 & 2.0 & & \\
\hline \multicolumn{5}{|c|}{ Do you have annual medical check up } \\
\hline Yes & 755 & 83.9 & & \\
\hline No & 145 & 16.1 & & \\
\hline
\end{tabular}

For the next part of the index, it focuses on the income. The respondents were asked to indicate the total of income per month they earned and then the total multiplied by 12 to gain their income per year. Looking at the mean score, it is good to know that the score recorded was RM 1,874.74, however when further analyses were done it revealed that $19.6 \%$ of the respondents earned only RM6000 and below per year which falls under the category of poverty level (RM720 x $12=\mathrm{RM} 8640)$. Majority of the respondents indicated that they managed to earn incomes between RM6000 - RM12000 per year. Interestingly, $16.0 \%$ of the respondents managed to earn incomes more than $>$ RM 30,001 (Table 6).

Table 6. Part 2: HDI Part 2 (Income)

\begin{tabular}{ccccc}
\hline & Frequency & Percentage & Mean & SD \\
\hline Estimated income per year & & & $\mathbf{1 8 7 4 . 7 4}$ & $\mathbf{5 3 7 5 . 5 3}$ \\
$\leq$ RM6000 & 176 & 19.6 & & \\
RM6001-RM12,000 & 251 & 27.9 & & \\
RM12,001-RM18,000 & 155 & 17.2 & & \\
RM18,001-RM30,000 & 174 & 19.3 & & \\
> RM30,001 & 144 & 16.0 & & \\
\hline
\end{tabular}

Part 3 of the index focuses on the level of education of the respondents. The respondents have been given an option of four answers for the questions in this section. Nearly two thirds of the respondents $(61.3 \%)$ did not complete high school/no diploma while a total of $31.7 \%$ possessed high school certification or equivalent level of education. A total of $4.8 \%$ of the respondents possessed some college credit or associate credit, but did not receive a bachelor degree. Only a small portion of the respondents $(2.0 \%)$ possess a bachelor degree from four years of college or university. Only 1 respondent $(0.1 \%)$ was identified to possess Master/Doctorate or Professional Degree (Table 7). 
Table 7. HDI Part 3 (Education)

\begin{tabular}{ccc}
\hline Level of education & Frequency & Percentage \\
\hline Did not complete high school/ no diploma & 553 & 61.4 \\
High school graduate or equivalent & 285 & 31.7 \\
Some college credit or associate credit, but did not receive a bachelor degree & 43 & 4.8 \\
Bachelor degree from four year college or university & 18 & 2.0 \\
Master/Doctorate of Professional Degree & 1 & 0.1 \\
\hline
\end{tabular}

Table 8 presents the data and will provide the answer for one of the main objectives of this study; to gain the HDI of the communities along Pahang and Muar Rivers and living within Pekan, Bahau and Muar. As been mentioned a total of 26 questions which covered health, income and education related questions were asked and all of their answers were keyed in into the well-o-meter index. The index will produce a maximum value of 10.0. The HDI gained then was keyed in into the SPSS and then a cumulative value for the index was calculated and producing the overall level of HDI for the respondents. Then, the cumulative value for the HDI was grouped into three groups namely low (1.00-4.01), moderate (4.01-7.00) and high (7.01-10.0).

Results presented in Table 8 conclude that HDI for rural the communities living along Pahang River and Muar River in Pekan, Bahau and Muar was low based on the mean score of 3.99 (from the maximum mean score of $10.0)$. Further analysis employed have specifically revealed to us that more than half of the respondents (57.8\%) have a low level of HDI and more than one third of the respondents $(36.6 \%)$ were detected to have a moderate level of HDI. Minority of the respondents (5.6\%) were identified to have a high level of HDI.

Table 8. Overall level of Pahang River and Muar River community development index using the American human development index (Well-O-Meter)

\begin{tabular}{ccccc}
\hline HDI Index Category & Frequency & Percentage & Mean & SD \\
\hline Low $(1.00-4.00)$ & 520 & 57.8 & & $\mathbf{3 . 9 9}$ \\
Moderate $(4.01-7.00)$ & 329 & 36.6 & & \\
High $(7.01-10.0)$ & 51 & 5.6 & & \\
\hline
\end{tabular}

Further analysis employed have revealed on the level of HDI on each of the cities studied. Results presented in Table 9 have ranked respondents in Bahau recorded the highest HDI $(M=4.10)$, followed by Muar $(M=4.02)$ and Pekan ( $\mathrm{M}=3.85)$. Specifically, a total of $34.7 \%$ of the respondents in Pekan, $36.0 \%$ of the respondents in Bahau and $39.0 \%$ of the respondents in Muar were identified to have a moderate level of HDI. It is good to know that $4.0 \%$ of the respondents in Pekan, $7.3 \%$ of the respondents in Bahau and $5.7 \%$ of the respondents in Muar were revealed to score a high level of HDI. Further analysis using ANOVA was employed to examine any difference that might occur between the three cities, however based on the $F$ value $(3,900)=1.748, p<0.05$, there was no significant difference detected (Table 10).

Table 9. Level of human development index in the three cities along Pahang River and Muar River

\begin{tabular}{cccccc}
\hline & HDI Index Category & Frequency & Percentage & Mean & SD \\
\hline \multirow{3}{*}{ Pekan } & Low $(1.00-4.00)$ & 184 & 61.3 & $\mathbf{3 . 8 5}$ & $\mathbf{1 . 5 7}$ \\
& Moderate $(4.01-7.00)$ & 104 & 34.7 & & \\
& High $(7.01-10.0)$ & 12 & 4.0 & & \\
& Low $(1.00-4.00)$ & 170 & 56.7 & $\mathbf{4 . 1 0}$ & $\mathbf{1 . 6 1}$ \\
Bahau & Moderate $(4.01-7.00)$ & 108 & 36.0 & & \\
& High $(7.01-10.0)$ & 22 & 7.3 & & \\
& Low $(1.00-4.00)$ & 166 & 55.3 & $\mathbf{4 . 0 2}$ & $\mathbf{1 . 6 8}$ \\
Muar & Moderate $(4.01-7.00)$ & 117 & 39.0 & & \\
& High $(7.01-10.0)$ & 17 & 5.7 & & \\
\hline
\end{tabular}


Table 10. Comparison between the three cities studied in term of HDI Index

\begin{tabular}{cccccc}
\hline Variables & $\mathbf{n}$ & Mean & SD & $\mathbf{F}$ & $\mathbf{p}$ \\
\hline HDI Index & & & & $\mathbf{1 . 7 4 8}$ & $\mathbf{. 1 7 5}$ \\
Pekan & 300 & 3.85 & 1.57 & & \\
Bahau & 300 & 4.10 & 1.61 & & \\
Muar & 300 & 4.02 & 1.68 & & \\
\hline
\end{tabular}

\section{Discussion}

There are several salient points that can ensue from the study regarding its novelty and the significance of the findings themselves. Firstly, this is one of the first studies in Malaysia where the HDI has been used as an instrument for a study of this nature. It is pertinent in that it is a real test as to whether the Malaysian human development condition can be gauged using an internationally utilised and the current benchmark measure of the United Nations.

It is very heartening to note, as evidenced from the study, that the HDI as a measuring tool can be used in Malaysia and this can encourage other researchers to use it as well. It remains a challenge to measure the HDI of other coverage units such as by district or by state.

The findings for the quality of life indicate that the seven dimensions being used are adequately viable to assess the quality of life of the range of communities along the Pahang-Muar Rivers. Pekan and Muar came out as having better scores on the quality of life measures and this can be explained by the vibrancy of developmental, economic and business activities in these two cities. These two cities are right at the mouths of the two mighty rivers, which historically and until recent times, have been socially and economically active. Bahau, on the other the other hand, is further in the hinterland and could not benefit from the bustling trading and port business.

When comparing Muar and Pekan, it is interesting to note that depending on the value one may place on the QOL dimensions, one can say that either Muar, with highest mean scores for Education, Financial and Job Security and Physical Environment, is better or just as good as Pekan, with highest mean scores for Social Involvement and Relationship, Safety in the Areas and Infrastructure.

Another interesting debate can arise from the result of the HDI measures and they did not significantly point out which city really has the better HDI, even though Bahau could also stand out to be counted. As found in the study, the HDI of all the cities studied were low to moderate. However, this certainly differs from the QOL dimensional measures mentioned earlier. This apparent discrepancy can be explained because the HDI is computed based on true figures and estimates, whilst the QOL dimensions were computed based upon the perception scores of the respondents and data compared within and among the three cities. On the other hand, the HDI measure is more global in nature. Nevertheless it is a useful and successful comparison and it remains to be further tested which measures would be more pertinent or better complement one another in similar studies in the future.

\section{Conclusion}

One of vital contributors to rural community development is QOL. It is a final indicator that is frequently emphasized. Analysing from the result obtained, it can be deduced that in all aspects studied, community that live along Pahang River and Muar River record high level of QOL. The community in Pekan have recorded the highest mean score in three aspects of quality of life which are 1) physical environment; 2) safety at the areas and 3) social involvement and relationship. Meanwhile, the community in Muar managed to record the highest mean score in three aspects namely 1 ) education; 2) financial and job security and 3 ) infrastructure facilities. The community in Bahau scored the highest mean score in home condition aspect. Ranking of the cities respective to the aspect of QOL studied is shown in Table 11 below. 
Table 11. Ranking of the cities in the aspects of quality of life studied

\begin{tabular}{cccc}
\hline Aspects of QOL & Ranking 1 & Ranking 2 & Ranking 3 \\
\hline Home condition & Bahau & Muar & Pekan \\
Physical environment & Pekan & Muar & Bahau \\
Safety at the areas & Pekan & Muar & Bahau \\
Social involvement and relationship & Pekan & Bahau & Muar \\
Education & Muar & Pekan Bahau & - \\
Financial and job security & Muar & Bahau & Pekan \\
Infrastructure facilities & Muar & Pekan & Bahau \\
\hline
\end{tabular}

Rural development is a crucial element of the rural community. However, this study has found that the level of human development index in rural community in Malaysia is still low. Nevertheless, several positive signs can be identified for overall respondents besides the low to moderate level of HDI discovered. Yet, it is arguable that the comparisons measurements of HDI used are similar with the United States. To understand this measure and phenomenon, more work has to be conducted. On the whole, one can surmise the following:

1) Respondents in Muar and Bahau did exceed the moderate level of HDI

2) Majority of respondents did exceed the recent poverty level established by the government

3) Majority of the respondents were not working after age 65

4) Majority of the respondents never live alone since their age of 25 years

5) The work of majority of the respondents did not require them to do a heavy physical work

6) Majority of the respondents did not have overweight problem

7) Majority of the respondents did perform their annual medical check-ups

\section{References}

Ahmad Faiz, A. N., Khairuddin, I., Jegak, U., Hayrol Azril, M. S., \& Jeffrey Lawrence, D. S. (2010). Aquaculture industry potential and issues: A case from cage culture system entrepreneurs: Suggestions for intensification of aquaculture industry. Social Science, 6(2), 206-211.

Azlina, M. Y., Eves, C., \& McDonagh, J. (2010). An evolution of waterfront development in Malaysia. Paper presented at 16th Pacific Rim Real Estate Society Conference, Wellington 24-27 January 2010.

City of Hood River. (2011). Hood River economic opportunities analysis. Retrieved May 8, 2012, from http://centralpt.com/upload/375/15522_HoodRiverEOAfinal.pdf

Ericson, E., \& Ronning, A. (2008). Sustainable tourism development in Cambodia: A report about positive and negative effects of international tourism. Retrieved March 1, 2012, from http://www.essays.se/essay/6cbfc2d1d7/

Grumbine, R. E., \& Xu, J. (2011). Mekong hydropower development. Science, 332, 178-179. http://dx.doi.org/10.1126/science.1200990

Hamilton, J. R., Huppert, D., Boire, K., Casavant, K., Peters, L., Richards, J., Scott, A., \& Sorensen, P. (1999). River Economics: Evaluating Trade-offs in Columbia River Basin Fish and Wildlife Programs and Policies. Retrieved on May 8, 2012, from http://www.nwcouncil.org/library/ieab/ieab1999-1.htm

Hayrol Azril, M. S., Ahmad Faiz, A. N., Khairuddin, I., Jegak, U., \& Jeffrey Lawrence, D. S. (2010). Agriculture project as an economic development tool to boost socio-economic level of the poor community: the case of agropolitan project in Malaysia. African Business Management, 4(11), 2354-2361.

Hitzhusen, F. J., Ayalasomalajula, R., \& Lowder, S. (1999). Economic valuation of river corridor. Integration of natural resource and development economics. Retrieved May 9, 2012, from http://ageconsearch.umn.edu/bitstream/21571/1/sp99hi01.pdf

Human Development Report 2010 - 20th Anniversary Edition: The real wealth of Nations: Pathways to human $\begin{array}{lllll}\text { development. } & \text { Retrieved } & \text { March } & 1, & \text { 2012, }\end{array}$ http://hdr.undp.org/en/media/HDR_2010_EN_Complete_reprint.pdf 
Jianwu, H., Chaoqian, Q., Yajing, T., \& Man, L. (2010). Economic and social influences of the water environment Vicissitude of Yangtze River Basin. Paper presented at 2010 International Conference on Challenges in Environmental Science and Computer Engineering. http://dx.doi.org/10.1109/CESCE.2010.57

Kristensen, J. (2001). Food security and development in the lower Mekong river basin: A challenge for the Mekong River commission. Paper presented at Asia and Pacific Forum on Poverty: Reforming Policies and Institutions for Poverty Reduction, Asian Development Bank, Manila, 5-9 February 2001.

McCartan, M., \& Brady, C. (2007). Middletown to Monaghan a social economic study of the benefits of the proposed reopening of the Ulster canal. Retrieved Februrary 28, 2012, from http://www.crossborder.ie/pubs/ulster_canal.pdf

Ministry of Rural and Regional Development. (2011). Rural Statistic. Retrieved January 2, 2012 from http://www.rurallink.gov.my/statistics

Misra, P. (2007). Dredging and integrated development of inland waterways. Paper presented at Twentieth National Convention of Marine Engineers, 24-25 February 2007, Visahapaknam, India.

Raja Zainuddin, R. O., Idris, K., Shaffril, H. A. M., Hamzah, A., Man, N., \& D’Silva, J. L. (2011). Potentials benefits and problems to be faced by interested youth in freshwater cage culture: the entrepreneur's experience. In Jamilah et al. (Eds.), Proceeding of Internatiounal Conference on Youth Development 2011 (pp. 607-613).

Sudar, A. (2005). Measuring non-traditional benefits and cost of inland navigation. Transportation Research Board, 3, 47-53. http://dx.doi.org/10.3141/1909-07

Yassin, M. S., Shaffril, H. A. M., Hassan, M. S., Othman, M. S., Samah, B. A., \& Samah, A. A. (2010). Socio-economic factors that impinge the quality of life of Muar River community. Australian Basic and Applied Science, 4(10), 5362-5371.

Yassin, M. S., Shaffril, H. A. M., Hassan, M. S., Othman, M. S., Samah, B. A., \& Samah, A. A. (2010). Sustainable livelihood along major rivers: The need for a new model and extension's response to the riverside development. Paper presented at International Conference on Agricultural Extension 2010, 26-28th October 2010, Palm Garden Hotel, IOI Resort Putrajaya, Malaysia.

The Human Development Concept. (2012). Retrieved January 4, 2012, from http://hdr.undp.org/en/humandev/

The American Human Development Project of the Social Science Research Council. (2011). The Human Development Index. Retrieved December 15, 2011, from http://www.measureofamerica.org/human-development/

Theerapappisit, P. (2003). Mekong tourism development: Capital or social mobilization? Tourism Recreation Research, 28(3), 47-56.

WHOQOL Group. (1993). Study protocol for the World Health Organization project to develop a quality of life assessment instrument (WHOQOL). Quality of Life Research, 2, 153-159. http://dx.doi.org/10.1007/BF00435734 